\title{
Effect of Cassava Mosaic Disease (CMD) on Yield and Profitability of Cassava and Gari Production Enterprises in Sierra Leone
}

\author{
Alusaine E. Samura ${ }^{1}$, Kepifri A. Lakoh ${ }^{2}$, Osman Nabay ${ }^{1}$, Sahr N. Fomba ${ }^{2}$ \& James P. C. Koroma ${ }^{2}$ \\ ${ }^{1}$ Sierra Leone Agricultural Research Institute (SLARI), Njala Agricultural Research Centre (NARC), Freetown, \\ Sierra Leone \\ ${ }^{2}$ Crop Protection Department, School, of Agriculture, Njala University, Freetown, Sierra Leone \\ Correspondence: Alusaine E. Samura, Sierra Leone Agricultural Research Institute (SLARI), Njala Agricultural \\ Research Centre (NARC), Freetown, P.O. Box 540, Sierra Leone. Tel: 232-76-731-554. E-mail: \\ aesamura@yahoo.com
}

Received: November 1, 2016

Accepted: December 17, 2016

Online Published: January 15, 2017

doi:10.5539/jas.v9n2p205

URL: http://dx.doi.org/10.5539/jas.v9n2p205

The research is financed by the Government of Sierra Leone through the West Africa Agricultural Productivity Programme (WAAPP).

\begin{abstract}
Cassava Mosaic Disease (CMD) seriously affects cassava (Samura et al., 2013; Fargette et al., 1988). There is limited information on tuberous root yield loss and the profitability of growing improved and local varieties infected with the cassava mosaic virus for tuber and gari production in Sierra Leone. The objectives of the study were to determine yield loss associated with cassava mosaic disease and conduct cost benefit analysis (budgets and break-even analysis) on cassava production using two improved varieties (SLICASS 4 and 6) compared against the local susceptible variety Cocoa, for gari production and Cocoa as a poundable enterprises for the boil and eat market. Activity 1 involved the establishment of a yield loss trial using the paired plot technique. Activity 2 assessed productivity of cassava and gari production. Data collected were analysed using the analytical frame work that incorporates the concept of gross margin analysis as describe by Brown (1979). This included cost benefit analysis (CBA), the net social benefit (NSB) or the excess of total benefit over total cost represents the net present value (NPV) and The Internal Rate of Returns (IRR).

The yield loss associated with the local variety Cocoa under this system was $4.27 \mathrm{t} / \mathrm{ha}$ which is equivalent to $38.92 \%$ yield loss resulting from the cassava mosaic disease infection. SLICASS 4 and SLICASS 6 recorded positive returns to production of tubers and gari. The local variety Cocoa enterprises for gari under the same condition recorded a negative returns even in the 6 year. However Cocoa for the boil and eat market had the highest profit level. The implication of this study is that breeding effort should be geared towards high yielding mosaic resistant varieties that are poundable more profitable and suits the cultural and domestic demand of the producers, processors and consumers.
\end{abstract}

Keywords: cassava mosaic disease, cassava genotypes, yields loss, profitability

\section{Introduction}

Cassava remains to be a major food security crops in Sierra Leone and is regarded as the most important root and tuber crop in the country (Fomba et al., 2012). Despite positive attempts by government to revive the agricultural sector, post-war levels of productivity are still very low, estimated at $7 \mathrm{t} / \mathrm{ha}$ (FAO, 2014). The tuber, which is a vital part of several local cuisines in West Africa, does not only serve as a major input in the production of food items, but also serves as a highly viscous and dense starchy input for several industries (in-edibles). The leaves are mainly used as vegetables (when cooked) and are sometimes used as cattle/sheep fodder. Over the last three decades (pre and post-war Sierra Leone), various types of research activities have been ongoing in the country. The Njala Agricultural Research Center (NARC), formally, Institute of Agricultural Research, has been conducting various types of research activities on cassava in the country. All of these strides were geared towards coming up with high yielding, disease free, drought tolerant and consumer friendly varieties for onward dissemination to smallholder farmers in the country. However, in spite of all these efforts, there continues to be 
severe challenges affecting the crop's productivity and hence, the rate of varietal adoption on farmer fields. The most important disease and leading constraint of cassava production in Africa is the African Cassava Mosaic Disease (ACMD) (Fregene et al., 2,000; Berry \& Rey, 2001). Farmers in Sierra Leone continue to cultivate local varieties infected with ACMD. A necessary first step to improved crop varietal selection by potential adopters (farmers) is to provide empirical answers to some fundamental socioeconomic issues that would encourage farmers to adopt new technologies. Some include identification of genotypes with traits that meets farmers demand. Also, the potential profits farmers stand to gain should they adopt the improved varieties against following their traditional varieties. Furthermore, and in line with the value chain approach promoted by the West African Agricultural Productivity Program (WAAPP), these improved crop varieties should be promoted beyond the tuber stage, to more value added products or enterprises like chips, gari, fufu, toa etc. Understanding the potential gains (in financial terms) that entrepreneurs stand to gain should they utilize the improved varieties to process gari, fufu or other up-stream products in vital for adoption.

It is against this background this research is carried out. The objectives of this research are therefore listed below:

1) To determine the effects of ACMD on the yield and yield components of cassava in Sierra Leone.

2) Conduct cost benefit analysis (budgets and break-even analysis) on cassava production in Sierra Leone for SLICASS 4 and SLICASS 6 compared against the local variety (Cocoa) used for gari and Cocoa used as a poundable variety.

3) Conduct cost benefit analysis of gari production as an upstream enterprise.

\section{Method}

Two activities were undertaken to determine the loss associated with the cultivation of cassava mosaic infected varieties. The first activity was geared towards determining yield loss in terms of tuberous root yield as a result of the African cassava mosaic disease. The second activity compared income derived from processing ACMD resistant and ACMD susceptible varieties per unit area of cassava.

\subsection{Activity 1: The Effects of Cassava Mosaic Disease (ACMD) on Yield and Yield Components of Infected and Symptomless Cuttings Derived from the Local Cassava Variety (Cocoa) in Sierra Leone}

\subsubsection{Preparation of Cuttings}

The local variety (Cocoa) known to be infected by the Cassava Mosaic Virus was used for this trial. Symptomless plantlets derived from the apical meristem of neem treated cassava cuttings were raised from three generations and multiplied for use in the cassava mosaic free plots. Before planting, cuttings were cut into $30 \mathrm{~cm}$ length and treated for $10 \mathrm{~min}$ in solution of benomyl $\left(2.5 \mathrm{~g}\right.$ a.i/ $\mathrm{L}$ of $\mathrm{H}_{2} \mathrm{O}$ and planted in polythene bags in the screen house for symptom observation before establishment field trials.

\subsubsection{Experimental Design}

The paired plot technique was used to compare cassava yield of mosaic infected and the mosaic free in three replications.

\subsubsection{Data Collection}

Data were collected from all plants. Data included plant height measured in centimeters from the surface of the pot to the top most expanded leaf using a well calibrated meter rule. Leaf number was calculated by counting the number of leaves at each sampling period. Cassava Mosaic Disease assessment was done using the 1-5 scale (IITA, 1990) where 1 represents no symptom expression and 5, severe symptom expression. Tuberous root yield was determined by harvesting forty plants to determine the weight per plot, and ten plants to determine the number of tubers, weight of tubers per plant. Leaf fresh weight was determine by weighing ten plants to determine the weight per plant, while the whole plot was used to estimate weight of leaf per plot and number of bundles per plot.

\subsubsection{Data Analysis}

Cassava Mosaic virus infected plots and mosaic symptomless plot were compared using analysis of variance and mean separated using the least significant difference test (LSD). Genstat statistical software version 8 was used to analyse the data. 


\subsection{Activity 2: Profitability of Cassava Mosaic Infected Variety and Cassava Mosaic Resistant variety in Gari Production Enterprise}

\subsubsection{Data Collection}

Primary and secondary data were collected. Primary data collected include a detail investigation on the production systems, utilization and marketing of three cassava varieties i.e. Cocoa (Local variety), SLICASS 6 and SLICASS 4 (improved varieties). Secondary information includes the relevant literature from other studies on cassava cultivation, processing and marketing. Primary data were collected in 2013 cropping season in collaboration with Village Hope, an American Non-Governmental organisation working with the Njala Agricultural Research Center (NARC) on cassava processing. This study involved thirty farmers, ten farmers each growing the mosaic resistant cassava variety Slicass 4 and 6 and another ten set of farmers growing the local cassava mosaic infected variety, Cocoa. Cassava tubers were bought from farmers' fields and harvested and transported to the processing centre using a Ford F250 truck. Harvested area from each group of farmers was calculated, tubers weighed before processing and after peeling, to determine the peeling loss. After grating and pressing mashed tubers, decanted weight of mash and total weight of gari produced were also recorded. Detailed records of the running costs inputs, and operational cost on the cultivation, processing and marketing of those varieties were taken on each batch processed. This was done to compare their inputs cost and gross farm gate benefits between the two cassava varieties.

\subsubsection{Method of Data Analysis}

Data collected were analysed using profitability, cost benefit ratio and simple descriptive statistics analysis. Profitability analysis uses the analytical frame work that incorporates the concept of gross margin analysis as describe by Brown (1979) and profit was employed to estimate the costs and returns of cassava and gari production in the study area. The Gross Margin formula is represented as:

$$
\mathrm{GM}=\mathrm{GI}-\mathrm{TVC}
$$

Where,

$\mathrm{GM}=$ Gross margin; $\mathrm{GI}=$ Gross income TVC $=$ Total variable cost.

The profitability was also represented symbolically by,

$$
\pi=\mathrm{TR}-\mathrm{TC}
$$

Where,

$\pi=$ profit $; \mathrm{TR}=$ Total revenue/gross income $; \mathrm{TC}=$ Total cost $[$ total fixed cost $(\mathrm{TFC})+$ Total variable cost (TVC)].

To calculate the Gross Margin (GM), the Total Variable Cost (TVC) was computed by aggregating the cost of cultivation to have the roots, processing and marketing components. Processing costs included the cost of carrying out the activities in the process flow of producing the products. For instance, gari production involved cost of roots and its transportation/handling (loading and off-loading) charges, peeling, washing, grating, pulverizing, and toasting (frying). Similarly, marketing costs involved bagging, cost of packaging materials (bags, polyethylene). The enterprise Total Revenue (TR) was computed by multiplying the quantity (Q) of processed product from 1 hectare of cassava farm by the price $(\mathrm{P})$ i.e. $\mathrm{Q} \times \mathrm{P}$. To assess the profitability of the two different cassava varieties in the study area, the means of the two varieties were compared using single factor analysis of variance (ANOVA).

The following assumptions were true for the study: 
Table 1. Economic assumptions used for profitability analysis of gari enterprise using improved and local varieties from 1 ha of cassava farms

\begin{tabular}{llll}
\hline Assumption & Cocoa & Slicass $\mathbf{4}$ & Slicass $\mathbf{6}$ \\
\hline Cost/Bag & 15,000 & 10,000 & 10,000 \\
Number of bags processed & 20 & 20 & 20 \\
Average weight per bag $(\mathrm{Kg})$ & 48 & 55 & 51.8 \\
Average weight of tubers processed & 950 & 1,100 & $1,037.7$ \\
Average yield per ha & 7.1 & 24.82 & 23.18 \\
Gari/tuber ration & 0.18 & 0.20 & 0.19 \\
Truck mpg & 12 & 12 & 12 \\
Cost of gasoline per gallon & 25,000 & 25,000 & 25,000 \\
Cost per mile for gas & 2,083 & 2,083 & 2,083 \\
Multiplier & 1.5 & 1.5 & 1.5 \\
Total cost per mile & 3,125 & 3,125 & 3,125 \\
Truck mile & 30 & 30 & 30 \\
Number of managers & 3 & 3 & 3 \\
Number of staff & 19 & 19 & 19 \\
Selling price & 2,500 & 2,500 & 2,500 \\
\hline
\end{tabular}

From the institute's breeding activities over the last ten years, the Sierra Leone Agricultural Research Institute has formally released fourteen improved cassava varieties. These varieties are hybrid forms with several improved traits ranging from pest and disease resistance, improved yield, high dry matter content poundability and more. Due to some data limitations, we would focus on the two most popular varieties SLICASS 4 and SLICASS 6 out of the fourteen SLICASS cassava varieties already released for the research. The main data requirements for this analysis were:

1) Input and output data for the different varieties of cassava;

2) Price data of the different inputs;

3) Market prices;

4) Input and output data for gari production and marketing.

For this research, input and output figures were obtained from following a group of 30 farmers through two growing seasons and keeping track of input quantities and harvests. These farmers grew all varieties tested independently. These farmers were based in the Njala Community, Mano dase and the surrounding villages and hence, received prompt technical support from researchers when needed. Price data were obtained from ongoing market prices of the respective inputs and the crops.

\subsubsection{Net Present Value}

In cost benefit analysis (CBA), the net social benefit (NSB) or the excess of total benefit over total cost represents the net present value (NPV). Therefore, in determining the NPV of a technology of improved cassava varieties, the cost (C) and benefit (B) is needed. The NSB is calculated by subtracting the cost stream from the benefit stream and is represented as follows: $\mathrm{NSN}=\mathrm{B}-\mathrm{C}$ (Gittinger, 1995).

In determining the NPV, applied a discount rate to the identified costs and benefits. It is necessary to discount costs and benefit occurring later relative to those occurring sooner. This is because, money received now can be invested and converted into a larger future amount and because people generally prefer to receive income now rather in the future (Hanley \& Spash, 1995). A future value into present values is known as discounting. Discounting requires knowledge of a rate known as a discount rate. The discount rate does not necessarily equate to the rate of interest offered at banks. The formula for discounting is as follows:

$$
\mathrm{PV}=\frac{\mathrm{X}_{\mathrm{t}}}{(1+\mathrm{r})^{\mathrm{t}}}
$$

Where,

$\mathrm{PV}$ is the present value; $\mathrm{X}_{\mathrm{t}}$ is the amount of money in year $\mathrm{t} ; \mathrm{r}$ is the rate of discount (expressed as a proportion, i.e. $10 \%=0.1$ ), and $t$ is the number of years from the present date. 
When all benefits and costs are converted to present values, comparison is possible. Comparison is commonly made using three decision-making criteria: net present value, internal rate of return, and the benefit-cost ratio.

\section{Internal Rate of Return}

An alternative approach to assessing an investment is the calculation of the internal rate of return (IRR) of the investment. The IRR is the discount rate that will make the net present value equal to zero. In simpler terms, the IRR is the interest rate that will make the investment just break even Ingersoll Jr and Ross (1992). If the IRR exceeds the minimum acceptable discount rate or the opportunity cost of money, the project is worth further consideration.

Investors would have to invest NPV more (a total of NPV + already invested amount) to get the cash flows shown at the said interest rate. Therefore the project has a value of NPV for investors. The interest rate is called the cost of capital, because it is the opportunity cost of funds-The rate investors can earn on alternative investments. A project is chosen if it costs less than the PV of its cash flows. More generally: take a project if its Net Present Value is positive.

\section{Results}

\subsection{Activity 1: The Effects of Cassava Mosaic Disease (ACMD) on Yield and Yield Components of Infected and} Symptomless Cuttings Derived from the Local Cassava Variety (Cocoa) in Sierra Leone

3.1.1 Disease Severity Expression of Cassava Mosaic Treated and Non-Treated Cassava Cuttings over Time

Cassava Mosaic Disease $(\mathrm{CMD})$ treated cuttings in the protected plot showed highly significant $\left(\mathrm{P}_{0.05}<0.001\right)$ reduction in the disease symptom expressed compared to the unprotected plot. Mean severity score for the protected plot was 1.1 while the unprotected plot was 2.9. Manifestation of symptoms appeared between 6 to 9 months after planting for the protected plot with cuttings raised from symptomless plants. In the ACMV infected plot disease symptom expression was as early as 1 month after planting. Disease severity significantly increased with time with 12 months after planting (MAP) accounting for the highest severity levels of 3.7 in the unprotected plot. In all the period of assessment the unprotected plot had higher severity scores compared to the protected plot (Table 2).

Table 2. ACMD severity of cassava mosaic treated and non-treated cassava cuttings as affected by months after planting in 2014

\begin{tabular}{lllllll}
\hline \multirow{2}{*}{ Treatment } & \multicolumn{7}{c}{ Months after planting (MAP) } & \multirow{2}{*}{ Mean } \\
\cline { 2 - 6 } & $\mathbf{1}$ & $\mathbf{3}$ & $\mathbf{6}$ & $\mathbf{9}$ & $\mathbf{1 2}$ & \\
\hline ACMD protected plot & 1.0 & 1.0 & 1.0 & 1.2 & 1.3 & 1.1 \\
ACMD infected plot & 2.0 & 2.0 & 3.3 & 3.3 & 3.7 & 2.9 \\
Mean & 1.5 & 1.5 & 2.2 & 2.3 & 2.5 & \\
$\mathrm{LSD}_{0.05}$ (Treatment)** & 0.16 & & & & & \\
$\mathrm{LSD}_{0.05}$ (MAP)** & 0.25 & & & & & \\
$\mathrm{LSD}_{0.05}$ (Treatment $\times$ MAP)** & 0.35 & & & & & \\
$\mathrm{CV}(\%)$ & 10.4 & & & & & \\
Note. & $* *=$ Significantly different at $\mathrm{P}_{0.05}<0.001$. & & & &
\end{tabular}

\subsubsection{Yield and Yield Component of Cassava Mosaic Disease Treated and Non-Treated Cassava Cuttings}

(1) Mean Number of Tubers per Plant

The protected plot with symptomless cuttings produced an average of 3.67 tubers per plant significantly $\left(\mathrm{P}_{0.05}<\right.$ 0.002 ) higher than the unprotected plot which produced an average of 2.0 tubers (Table 3 ).

(2) Number of Tubers per Plot

A similar trend was observed in terms of total number of tubers produced per plot as in the number of tubers produced per plant. The protected plot produced an average of 107 tubers per plot when harvested at 12 months after planting and was significantly $\left(\mathrm{P}_{0.05}<0.011\right)$ higher than the unprotected plot which produced an average of 71.7 tubers (Table 3 ). 


\section{(3) Average Weight of Tubers per Plant}

The protected plot with symptomless cuttings produced an average weight of $0.41 \mathrm{~kg}$ per plant not significantly $\left(\mathrm{P}_{0.05}<0.093\right)$ higher than the unprotected plot which produced an average $0.37 \mathrm{~kg}$ per plant (Table 3$)$.

(4) Weight of Tubers per Plot

The protected plot produced an average weight of $43.9 \mathrm{~kg}$ per plot when harvested at 12 months after planting and was significantly $\left(\mathrm{P}_{0.05}<0.007\right)$ higher than the unprotected plot which produced an average of $27.1 \mathrm{~kg}$ (Table 3).

(5) Tuberous Root Yield (t/ha).

Tuberous root yield for the protected plot, from which symptomless plant were raised, produced $10.97 \mathrm{t} / \mathrm{ha}$ significantly $\left(\mathrm{P}_{0.05}<0.001\right)$ higher than the ACMD infected plot which produced $6.70 \mathrm{t} / \mathrm{ha}$.

(6) Yield Loss Associated with Cassava Mosaic Disease from the Local Variety Cocoa

Result from the tuberous yield of infected and symptomless plots revealed that symptomless plot had $10.97 \mathrm{t} / \mathrm{ha}$ while the infected plot had $6.7 \mathrm{t} / \mathrm{ha}$. The yield loss associated with the local variety Cocoa under this system was $4.27 \mathrm{t} / \mathrm{ha}$ which is equivalent to $38.92 \%$ yield loss resulting from the cassava mosaic disease infection.

Table 3. Yield and yield component of cassava mosaic treated and non-treated cassava cuttings

\begin{tabular}{llllll}
\hline Treatment & $\begin{array}{l}\text { Average Number of } \\
\text { tubers per plant }\end{array}$ & $\begin{array}{l}\text { Number of } \\
\text { tubers per plot }\end{array}$ & $\begin{array}{l}\text { Average Weight of } \\
\text { tubers per plant }\end{array}$ & $\begin{array}{l}\text { Weight of } \\
\text { tubers per plot }\end{array}$ & Yield (t/ha) \\
\hline ACMD protected plot & 3.67 & 107 & 0.41 & 43.9 & 10.97 \\
ACMD infected plot & 2.0 & 71.7 & 0.37 & 27.1 & 6.7 \\
Mean & 2.8 & 89.3 & 0.39 & 35.5 & 8.8 \\
LSD $_{0.05}$ Treatment & $0.286^{* *}$ & $16.29 *$ & $6.06 \mathrm{NS}$ & $1.95^{* *}$ & $0.66^{* *}$ \\
CV (\%) & 2.9 & 5.2 & 3.8 & 4.9 & 2.1 \\
\hline
\end{tabular}

Note. $*$ = Significantly different at $\mathrm{P}<0.005 ; * *=$ significantly different at $\mathrm{P}_{0.005}<0.001 ; \mathrm{NS}=$ Not significantly different.

\subsection{Activity 2: Profitability of Cassava Mosaic Infected Variety and Cassava Mosaic Resistant Varieties in Gari Production}

In this section, the key results obtained from our analysis include cassava production and profitability, followed by gari profitability. This includes net annual cash flow for the different varieties assessed and the net present value of the enterprises. Four scenarios were examined. These were Slicass 4; Slicass 6, Cocoa used for the gari market and Cocoa used for the poundability market (boil and eat market). The main thrust of this economic analysis is to identify the profitability of the different enterprises by comparing profitability of the mosaic resistant varieties (SLAICASS 4 and 6) to the local mosaic infected variety (Cocoa) as stated above.

3.2.1 Net Annual Cash Flow of SLICASS 6, 4 and Cocoa for Gari Production and Cocoa for the Boil and Eat Market in Cassava Production

Table 4 shows the net annual cash flow that farmers get when they grow cassava for any of the four enterprises (SLICASS 6, 4 and Cocoa for gari production and cocoa for the boil and eat market). It also shows the break even points. That is, the year the different enterprises start recording positive returns. The result indicated that farmers growing SLICASS 4 and SLICASS 6 at a buying price of Le 8,000 per $50 \mathrm{~kg}$ bag (Le160/kg) for the gari industry started recording positive returns from the first year of operation, while the local variety Cocoa enterprises for gari under the same condition recorded a negative returns even in the 6 year. However Cocoa for the boil and eat market at a price of Le 40,000 commanded had the highest profit level compared to SLICASS 4 and SLICASS 6. 
Table 4. Net annual cash flow of improved cassava genotype SLICAS 6, 4 and Cocoa used for gari and Cocoa used for it poundability

\begin{tabular}{lllllll}
\hline & \multicolumn{5}{c}{ Cash Flow (Le) Showing Break-Even Point } \\
\cline { 2 - 7 } & Year 1 & Year 2 & Year 3 & Year 4 & Year 5 & Year 6 \\
\hline Slicass 6 & 241,905 & 230,385 & 219,415 & 208,966 & 199,016 & 189,539 \\
Slicass 4 & 409,524 & 390,023 & 371,450 & 353,762 & 336,916 & 320,873 \\
Cocoa-Garri & $-777,143$ & $-740,136$ & $-704,891$ & $-671,325$ & $-639,357$ & $-608,912$ \\
Cocoa-Poundability & $3,763,810$ & $3,584,580$ & $3,413,886$ & $3,251,320$ & $3,096,495$ & $2,949,043$ \\
\hline
\end{tabular}

Note. For the, Cocoa variety, market prices vary depending on the type of demand. Huge volumes are sold to the gari industry at Le 8,000 per $50 \mathrm{~kg}(\mathrm{Le} 160 / \mathrm{kg})$ bag while small stocks are sold at the local market at Le 40,000 per bag (Le 800/ kg).

Exchange rate: $1 \$=$ Le 5,582.23

3.2.2 Net Present Value (NPV) at Different Interest Rates for SLICASS 4, 6 and the Local Cassava Variety Cocoa for Gari and Cocoa for Poundability

Market dynamics change regularly. This makes profit estimates not an accurate measure that can be used to advise adoption of an enterprise or technology. A more proper measure is the Net Present Value. That is the value of an enterprise in today's conditions. The table 5 below presents NPV estimates for the four enterprises considered in this study using the tubers, leaves and stems as marketable upstream products.

Table 5. Net present value at different interest rates for SLICAS 4, 6 and the local cassava variety Cocoa for gari and Cocoa for poundability

\begin{tabular}{lllllll}
\hline \multirow{2}{*}{ Cassava Varieties } & \multicolumn{5}{c}{ Annual discount (\%) (Le) } \\
\cline { 2 - 7 } & $10 \%$ & $12 \%$ & $14 \%$ & $16 \%$ & $18 \%$ & $20 \%$ \\
\hline Slicass 4 & $1,312,074$ & $1,219,898$ & $1,136,509$ & $1,060,877$ & 992,117 & 727,656 \\
Slicass 6 & 756,766 & 702,639 & 653,691 & 609,315 & 568,987 & 414,082 \\
Cocoa for gari & $-2,619,249$ & $-2,442,061$ & $-2,281,623$ & $-2,135,983$ & $-2,003,451$ & $-2,003,451$ \\
Cocoa for Poundability & $13,370,041$ & $12,424,528$ & $11,570,957$ & $10,798,355$ & $10,097,267$ & $9,459,524$ \\
\hline
\end{tabular}

Note. Exchange rate: $1 \$=$ Le 5,582.23.

At the going market interest rate (between 10 and 20\%) SLICASS 4 SLICASS 6 and the Cocoa used as an enterprise for poundable variety were profitable with the poundable Cocoa enterprise having the highest value. The Cocoa enterprise when used for gari was not profitable at any given interest rate having the lowest value. This means that this enterprise is clearly unfavorable. The SLICASS 4 enterprise had a higher value compared to SLICASS 6. This is further projected in the Figure 1 below: 


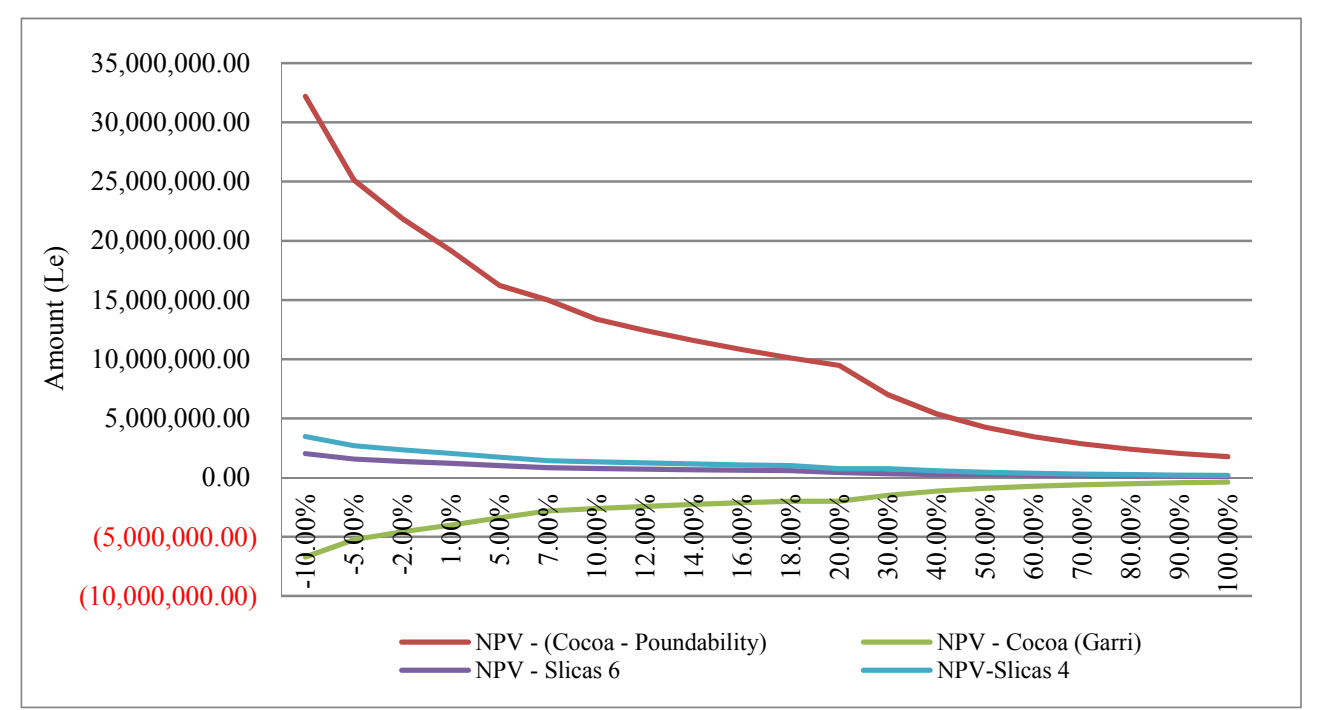

Figure 1. Graph showing NPV for SLICAS 4, 6, Cocoa used for gari and Cocoa used for poundability Note. Exchange rate at the time of the study $1 \$=$ Le 5,582.234.

3.2.3 Net Annual Cash Flow for Gari Processing and Sales in Freetown, Njala and with World Food Programme (WFP)

This section presents data on gari profitability (Market Effect) irrespective of the variety used. The assumption here is that there was little difference in the fresh tuber and gari conversion ratio for Cocoa, Slicass 4 and 6. Therefore for equal amount of fresh tuber processed, estimate of gari production was similar for each variety.

(1) Gari Profitability (Market Effect) Cash Flow for Gari Enterprise at World Food Programme (WFP), Freetown and Njala Prices

Based on cost of gari per kg at Njala, Freetown and the World Food programme (WFP) price at the time of the study which was Le 2,500, le 3,500 and Le 2,500 respectively for each location, it was not profitable to sell at Le 2,500 at Njala due to the high cost of packaging, and transportation incurred at the processing centre. Under such condition profit can only be realized at the seventh month of operation unlike the situation in Freetown where cash flow was Le13, 363,045.7 at the first year at the price of Le 3,500 per $\mathrm{kg}$ despite the same level of expenditure as Njala. The WFP scenario presented a better option since the product is sold in bulk with no packaging cost, marketing cost and transportation cost. Under this circumstance the cash flow was calculated at Le 18,149,125.7 in year 1 (Table 6). 
Table 6. Gari profitability (Market Effect) cash flow for gari enterprise at world food programme, Freetown and Njala prices (by year)

\begin{tabular}{llll}
\hline \multirow{2}{*}{ Year(s) } & \multicolumn{3}{c}{ Cash Flows (Le) } \\
\cline { 2 - 4 } & WFP & Freetown & Njala \\
\hline 1 & $\mathbf{1 8 , 1 4 9 , 1 2 5 . 7}$ & $\mathbf{1 3 , 3 6 3 , 0 4 5 . 7} .70,139,162.3$ \\
2 & 60298251.39 & 50726091.39 & -16278324.61 \\
3 & 102447377.1 & 88089137.09 & -12417486.91 \\
4 & 144596502.8 & 125452182.8 & -8556649.216 \\
5 & 186745628.5 & 162815228.5 & -4695811.52 \\
6 & 228894754.2 & 200178274.2 & -834973.824 \\
7 & 271043879.9 & 237541319.9 & $\mathbf{3 0 2 5 8 6 3 . 8 7 2}$ \\
8 & 313193005.6 & 274904365.6 & 6886701.568 \\
9 & 355342131.3 & 312267411.3 & 10747539.26 \\
10 & 397491257 & 349630457 & 14608376.96 \\
11 & 439640382.7 & 386993502.7 & 18469214.66 \\
12 & 481789508.4 & 424356548.4 & 22330052.35 \\
\hline
\end{tabular}

Note. Exchange rate: $1 \$=$ Le 5,582.23.

This is further projected on a monthly basis where profit of Le 586,990 was observed in the 7th month of operations for the WFP scenario and a profit of Le 908,697 observed in the $8^{\text {th }}$ month of operation for the Freetown market (Table 7).

Table 7. Cash flows for gari enterprise for WFP and Freetown markets based on locations (by month)

\begin{tabular}{lll}
\hline \multirow{2}{*}{ Month } & \multicolumn{1}{c}{ Cash Flows (Le) } \\
\cline { 2 - 3 } & WFP & Freetown \\
\hline 1 & $-20,487,573$ & $-20,886,413$ \\
2 & $-16,975,146$ & $-17,772,826$ \\
3 & $-13,462,719$ & $-14,659,239$ \\
4 & $-9,950,291$ & $-11,545,651$ \\
5 & $-6,437,864$ & $-8,432,064$ \\
6 & $-2,925,437$ & $-5,318,477$ \\
7 & $\mathbf{5 8 6 , 9 9 0}$ & $-2,204,890$ \\
8 & $4,099,417$ & $\mathbf{9 0 8 , 6 9 7}$ \\
9 & $7,611,844$ & $4,022,284$ \\
10 & $11,124,271$ & $7,135,871$ \\
11 & $14,636,699$ & $10,249,459$ \\
12 & $18,149,126$ & $13,363,046$ \\
\hline
\end{tabular}

Note. Exchange rate: $1 \$=$ Le 5,582.23.

(2) Break-Even Point from Total Revenue (TR) and Total Cost (TC) for Gari Production

Break- even point for processing of cassava to gari as an enterprise can only be attained at the $8^{\text {th }}$ year of operation primarily due to high capital investment. At this point total revenue derived from gari was Le1, 200,000,000 while total cost was Le 1,193,113,298 when 1 ton of fresh tubers were processed daily for the 8 year period (Table 8). 
Table 8. Break-even point from Total Revenue (TR) and Total Cost (TC) for gari production using the local variety Cocoa

\begin{tabular}{lll}
\hline Years & Total Revenue & Total Cost \\
\hline 0 & & $24,000,000$ \\
1 & $150,000,000$ & $170,139,162.3$ \\
2 & $300,000,000$ & $316,278,324.6$ \\
3 & $450,000,000$ & $462,417,486.9$ \\
4 & $600,000,000$ & $608,556,649.2$ \\
5 & $750,000,000$ & $754,695,811.5$ \\
6 & $900,000,000$ & $900,834,973.8$ \\
7 & $1,050,000,000$ & $1,046,974,136$ \\
8 & $1,200,000,000$ & $1,193,113,298$ \\
9 & $1,350,000,000$ & $1,339,252,461$ \\
10 & $1,500,000,000$ & $1,485,391,623$ \\
11 & $1,650,000,000$ & $1,631,530,785$ \\
12 & $1,800,000,000$ & $1,777,669,948$ \\
\hline
\end{tabular}

(3) Net Present Value (NPV) for Gari Production and Marketing in Different Locations (WFP, Freetown and Local)

Net Present Values (NPV) shows that it is profitable to market gari in Freetown and or supply to the World Food Programme at an interest rate of $10 \%$ to $60 \%$ while local sale at Njala would not be profitable even if the enterprise is subsidized (Figure 2).

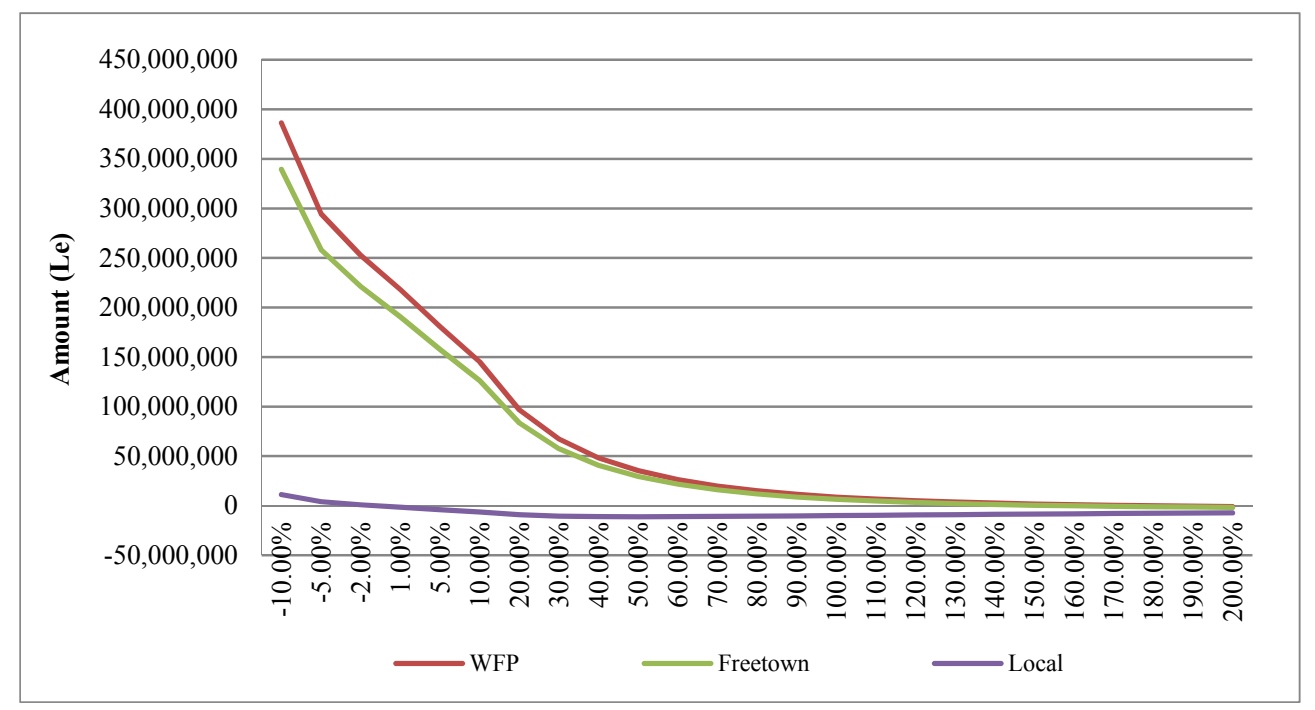

Figure 2. NPV for garri production and marketing in different locations (WFP, Freetown and local)

\section{Discussion}

Net Cash Flow which is the profits of the business plus non-cash expenses was used to determine profitability of gari enterprise from mosaic infected and mosaic resistant cassava varieties. In this study an attempts was made to show the effect of cassava mosaic disease on root yield production and production of gari from a local infected Cocoa variety and resistant improved cassava varieties (SLICASS 4 and 6) per hectare. The steps carried out for gari production are consistent with modern gari processing technologies (Sanni et al., 2009; Ijigbade et al., 2014).

In Sierra Leone, gari enterprise gave positive returns for improved cassava varieties compared to the susceptible local variety Cocoa. This result compliment report on profitability of gari in Ghana which confirmed that gari 
production business is a profitable and viable enterprise which can drive high income generation based on a benefit cost ratio of 1.33 and profitability ratio of 0.33 (Ijigbade et al., 2014).

Nweke et al. (2002) further stated that farmers who planted improved varieties (TMS varieties) in Nigeria produced yield which were $40 \%$ higher than that of local varieties even when grown without fertilizer. Report from IITA also indicates that improved varieties have contributed an extra 1.4 million tons of gari per year than would have been available from local varieties. In the same study profitability of TME varieties depended on the available grating technology.

Financial analysis shows that farmers who plant local varieties and grate manually earned the least revenue per ton of gari while farmers who plant local varieties and use mechanical grating earned higher. Improved varieties using mechanical grated earned the highest per ton of gari (Nweke et al., 2002).

Further analysis using the Net Present Value (NPV) which is the difference between the present value of the future cash flows from an investment and the amount of investment was done to check the viability of the enterprise. In this study NPV at different interest rates for SLICASS 4, 6 and Cocoa (the local cassava variety) using an interest rate of $10 \%$, it shows that SLICASS 4 enterprise has more value than SLICASS 6 and the traditional enterprises. The local variety as an enterprise had negative NPV at $10 \%$ interest rate. This means that this enterprise is clearly unfavorable. A zero net present value means the project repays original investment plus the required rate of return. A positive net present value means a better return, and a negative net present value means a worse return, than the return from zero net present value. An intrest rate ranging from $10 \%$ to $20 \%$ was used to assess the profitability of the enterprises based on the current intrest rate on loan levied by commercial banks; however a wider intrest rate was expressed to determine different senarios at which the various enterises could be profitable. Based on cost of gari per kg at Njala, Freetown and the World Food program (WFP) price at the time of the study which was Le 2,500, Le 3,500 and Le 2,500 respectively, it was not profitable to sell at Le 2,500 at Njala due to the high cost of packaging, transportation incurred at the processing center. Under such condition profit can only be realized at the seventh month of operation unlike the situation in Freetown where cash flow was Le13, 363,045.7 at the first year at Le the price per kg was Le 3,500 despite the same level of expenditure as Njala. The WFP scenario presented a better option since the product is sold in bulk with no packaging cost, marketing cost and transportation cost.

Attaining such economic benefit from improved cassava varieties come with huge challenges which creates bottle necks in the processing of cassava to gari. Constraints such as harvesting of tubers, transportation of tubers within farm and to processing centers, peeling of tubers whiles ensuring minimal tuber rot makes the who enterprise a challenge.

\section{Conclusion}

Yield loss as a result of cassava mosaic disease was estimated in this study and revealed that number of tubers increased from 2.0 to 3.67 tubers per plant with an increase in weight from $0.3 \mathrm{~kg}$ to $0.41 \mathrm{~kg}$ per plant when symptomless cutting derived from the local infected variety Cocoa was used. The yield loss associated with the local variety Cocoa under this system was $4.27 \mathrm{t} / \mathrm{ha}$ which is equivalent to $38.92 \%$ yield loss resulting from the cassava mosaic disease infection.

The assumption used for the gari enterprise was based on commercial production of cassava using tractors and modern input and took into account yield potential for each variety assessed. Calculations based on Net Cash Flow analysis shows that the.SLICASS 4 and SLICASS 6 enterprises start recording positive returns earlier than the local cassava enterprises which recorded negative returns even in the 6 year. The same variety Cocoa used as poundable variety enterprise for the boil and eat market had the highest returns.

Further analysis using the Net Present Value (NPV) for SLICAS 4, 6 and Cocoa (the local cassava variety) using an interest rate of $10 \%$, it shows that growing and processing improve varieties such as SLICASS 4 and SLICASS 6 was more profitable for a gari enterprise compared to the local mosaic infected variety Cocoa. However growing cocoa for the boil and eat market was the most profitable enterprise. Price influenced the overall profitability of gari enterprise. Based on cost of gari per $\mathrm{kg}$ at Njala, Freetown and the World Food program (WFP) price at the time of the study which was Le 2,500, le 3,500 and Le 2,500 respectively, it was not profitable to sell at Le 2,500 at Njala due to the high cost of packaging, transportation incurred at the processing center.

\section{Acknowledgements}

The authors wish to acknowledge the Government of Sierra Leone through the Ministry of Agriculture Forestry and Food security (MAFFS) The World Bank and The West African Agricultural Productivity Programme 
(WAAPP) for the financial and technical support provided for this project. I wish to acknowledge staff of Njala University, Dr Jim A. B. Whyte of International Institutes of Tropical Agriculture and Dr Abdul Raman Conteh, Director, Njala Agricultural Research Center for their technical input and supervision throughout this study. I wish to thank all collegues who participated in the preparation of manuscript.

\section{References}

Berry, S., \& Rey, M. E. C. (2001). Molecular evidence for diverse populations of cassava-infecting begomoviruses in southern Africa. Archive of Virology, 146, 1795-1802. http://dx.doi.org/10.1007/s0070 50170065

Brown, R. S., Caves, D. W., \& Christensen, L. R. (1979). Modelling the structure of cost and production for multiproduct firms. Southern Economic Journal, 256-273. http://dx.doi.org/10.2307/1057018

FAO of the United Nations. (2014). FAOSTAT. Rome, Italy. Retrieved September 11, 2016, from http://faostat.fao.org

Fomba, S. N., Massaquoi, F. B., Samura, A. E., Fornah, D. S., Benya, M. T., Dixon, A. G. O., ... Sanni, L. O. (2012). Innovative systems to improve small to medium scale cassava processing in Sierra Leone. In Y. U. Okechukwu \& P. Ntawuruhunga (Eds.), Proceedings of the 11th Triennial Symposium of the ISTRC (pp. 603-616). AB Held at Memling Hotel, Kinshasa, D. R. Congo, October 4-8, 2010.

Fregene, M., Bernal, A., Duque, M., Dixon, A., \& Tohme, J. (2000). AFLP analysis of African cassava (Manihot esculenta Crantz) germplasm resistant to the cassava mosaic disease (CMD). Theor. Appl. Genet., 100, 678-685. http://dx.doi.org/10.1007/s001220051339

Gittinger, J. (1995). Economic analysis of agricultural projects. Economic Development Institute Series in Economic Development. John Hopkins University Press. http://dx.doi.org/10.1017/s0014479700022894

Hanley, N., Spash, C., \& Walker, L. (1995). Problems in valuing the benefits of biodiversity protection. Environmental and Resource Economics, 5(3), 249-272. http://dx.doi.org/10.1007/bf00691519

Ijigbade, J. O., Fatuase, A. I., \& Omisope, E. T. (2014). Conduct and Profitability of Gari production for increased food security in Ondo State, Nigeria. IOSR Journal of Humanities and Social Science, 19, 89-95. http://dx.doi.org/10.9790/0837-19758995

Ingersoll Jr, J. E., \& Ross, S. A. (1992). Waiting to invest: Investment and uncertainty. Journal of Business, 1-29. http://dx.doi.org/10.1086/296555

International Institiue of Tropical Agriculture. (1990). Cassava in Tropical Africa, A Reference Manual. Ibadan, Nigeria: International Institute of Tropical Agriculture (IITA).

Nweke, F. I., Spencer, D. S. C., \& Lynam, J. K. (2002). The cassava transformation. Africa's best kept secret. East Lansing: Michigan State University. http://dx.doi.org/10.5860/choice.39-6428

Sanni, L. O., Oluwatobi, O., Onadipe, P. I., Mussagy, M. D., Abass, A., \&Dixon, A. G. O. (2009). Successes and challenges of cassava enterprises in West Africa: A case study of Nigeria, Bénin, and Sierra Leone. Ibadan, Nigeria: International Institute of Tropical Agriculture.

\section{Copyrights}

Copyright for this article is retained by the author(s), with first publication rights granted to the journal.

This is an open-access article distributed under the terms and conditions of the Creative Commons Attribution license (http://creativecommons.org/licenses/by/4.0/). 